succession of brief essays on most of the terms used in descriptions of the external anatomy of insects. Snodgrass wrote always a fine style of lucid English. $\mathrm{He}$ had a feeling for words, an interest in their etymology, and a gift for clear definitions. All these charactoristics are evident in this contribution.

\section{Prof. Eugène Pittard}

'THe Bulletin de la Société Suisse d'Anthropologie et d'Ethnologie for 1962-63 contains an excellent appreciation of the late Prof. Eugène Pittard of Geneva, who died a littlo while ago, aged ninety-five. Pittard was a delightful individual full of enthusiasm. One always looked forward to meeting him at archæological and anthropological congresses and similar functions. He started out as a zoologist, but soon found that anthropology was his real interest and vocation. He was no narrow spocialist; everything concerning man, whether physical or cultural, interested him. Thus when prehistoric archæology blossomed towards the start of tho prosent century Pittard was one of its foremost exponents. The University of Geneva eventually, in 1916, provided him with a professorial chair, and three years later with a suitable laboratory. In these days of narrow specialization it is pleasant to rocall one who had wide interests and yet was always in the forefront of knowledgo $\mathrm{He}$ wrote many works and the 'appreciation' concludes with a list of his more important publications.

\section{The Bowles Memorial Travel Scholarship}

THE Bowles Memorial Travel Scholarship was established by the Royal Horticultural Society as a memorial to the late E. A. Bowles (1865-1954). The objoct of the Scholarship is to enable the holder to travel abroad for either or both of the following purposes: $(a)$ the collection of plants for introduction to British gardens; (b) the study of practical horticulture in other countrios. For the years 1964 and 1965 a sum of $£ 500$ will be made available for award. Applicants for the Scholarship must be of the male sex, not more than twenty-eight years of age on January 1, 1964, and be a holder of the National Diploma in Horticulture, or a student of, or graduate in, horticulture or botany at a British university, or a past or present student-gardener at the University Botanic Garden, Cambridge, the Royal Botanic Garden, Edin. burgh, the Royal Botanic Gardens, Kew, the Royal Horticultural Society's Gardens, Wisley, or other horticultural educational establishment. Applications should be sent, by November 30 , to the Secretary of the Royal Horticultural Society, Vincent Square, London, S.W.1, from whom further information can be obtained.

\section{The Night Sky in November}

FULL moon occurs on Nov. Id $13 \mathrm{~h} 56 \mathrm{~m}$ U.T., new moon on Nov. $16 \mathrm{~d} 06 \mathrm{~h} 51 \mathrm{~m}$ and full moon on Nov. $30 \mathrm{~d} 23 \mathrm{~h} 55 \mathrm{~m}$. The following conjunctions with the Moon occur: Nov. $18 \mathrm{~d} 04 \mathrm{~h}$, Venus $3^{\circ}$ S.; Nov. 18d 07h, Mars $3^{\circ}$ S.; Nov. $2305 \mathrm{~h}$, Saturn $2^{\circ} \mathrm{N}$.; Nov. $27 \mathrm{~d} 00 \mathrm{~h}$, Jupiter $4^{\circ} \mathrm{N}$. In addition to these conjunctions with the Moon, Mars is in conjunction with Antares on Nov. 6d 16h, Mars being $4^{\circ}$ N., Venus with Antares on Nov. $12 \mathrm{~d} 11 \mathrm{~h}$, Venus being $4^{\circ} \mathrm{N}$., and Venus with Mars on Nov. 20d 22h, Venus boing $0.05^{\circ} \mathrm{S}$. Mercury, Venus and Mars are too close to the Sun for easy observation. Jupiter sets at $4 \mathrm{~h} 30 \mathrm{~m}, 3 \mathrm{~h} 25 \mathrm{~m}$ and $2 \mathrm{~h} 25 \mathrm{~m}$ on November 1,15 and 30 , respectively. It is in Pisces, its stellar magnitude is -2.4 and its distance from the Earth on November 15 is 385 million miles. Saturn sets at $23 \mathrm{~h} 10 \mathrm{~m}, 22 \mathrm{~h} 15 \mathrm{~m}$ and $21 \mathrm{~h} 25 \mathrm{~m}$ at the beginning, middle and end of the month, respectivoly. It is in Capricornus, its stellar magnitude is +0.9 , and its distance from the Earth on November 15 is 920 million miles. Occultations of stars brighter than magnitudo 6 are as follows, observations being made at Greenwich: Nov, 3d $20 \mathrm{~h} 09 \cdot 5 \mathrm{~m}, 97$ Tau. $(R)$; Nov. $4 \mathrm{~d} 4 \mathrm{~h} 1 \mathrm{I} \cdot \mathrm{lm}, 106$ Tau.
(R). $R$ refers to reappearance. The Taurid meteors are active during the first fortnight of the month, but conditions for observation are unfavourable. The Biolid meteors are expected about November 15, the radiant being near R.A. $1 \mathrm{~h} 32 \mathrm{~m}$, Dec. $+43^{\circ}$; conditions for observation are favourable. The Leonid moteors are active during November 14-17 with a maximum on November 16-17; the radiant is near R.A. $10 \mathrm{~h} 8 \mathrm{~m}$, Dec. $+22^{\circ}$, and conditions for observation are very favourable.

\section{Announcements}

Dr. J. H. Hodgson, chief of the Seismology Division of the Dominion Observatory, Canada, has been electod president of the International Association of Seismology and Physies of the Earth's Interior. Dr. Hodgson is a director of the Seismology Society of America as woll as being a member of various international committees. He was assistant professor of geophysics in the University of Toronto from 1945 until 1949.

THE British Institute of Radiology is holding a meeting on Octobor 17, at which the presidential address "Nothing New?" will be given by Prof. C. B. Allsopp. Further information can be obtained from the General Secretary, British Institute of Radiology, 32 Welbeck Street, London, W.1.

A MeEring to celebrate the centenary of Dr. L. H. Backeland (1863-1944), the inventor of 'Bakelite', arranged by the Royal Flemish Society of Engineers and the Flemish Chemical Society, will be held in the State University of Ghent during November 22-23. Further information can be obtained from Dr. R. Thiors, Ingenieurshuis, Jan van Rijswijcklaan 58, Antwerpen I.

Twerve public lectures on "The History of Medicine" will be delivored by Dr. Edwin Clarke in the Wellcome Historical Medical Library, London, on Tuesdays and Thursdays commencing October 15. Further information can be obtained from the Wolleome Historical Medical Library, the Wellcome Building, Euston Road, London, N.W.1.

A MeEting of the Biochemical Society will be held in the Department of Physiology and Biochemistry, the University of Southampton, on October 18. Included in the programme will be a colloquium on "Comparative Biochemistry and Physiology" (chairman, K. A. Munday). Further information can be obtained from H. R. V. Arnstein, National Institute for Medical Research, the Ridgeway, Mill Hill, London, N.W.7.

A symposium on "The Natural History of Aggression", arranged by the Institute of Biology, will be held at the British Museum (Natural History) during October 21-22. Topics under discussion will include: ritualized fighting in animals; aggression in societios of apes; the physiological background to aggression; aggression and montal illness; the origins of war; possible substitutes for war; the nature of aggrossion as revealed by the atomic age. Further information can bo obtained from the Institute of Biology, 41 Queen's Gate, London, S.W.7.

A practidar four-week residential course in "Administration and Management of Research and Development", arranged by the Comparative Administration Trust, will bo hold at the Sundridge Park Management Centre, Bromley, during November 10-December 7. Tho aim of the course is to improve the practical effectiveness of those ongaged in administration and management of technical work in industry, in industrial resoarch associations or publicly sponsored research establishments. Topics to be considered will include: the nature of the individual and of tho team; the teams in their wider context; special problems of science and technology. Further information and forms of application can be obtained from the Comparative Administration Trust, 30 St. George Street, Hanover Square, London, W.1. 